\title{
Low-intensity tower climbing resistance exercise reduces experimentally induced atopic dermatitis in mice
}

\author{
Jooyoung Kim* \\ Department of Anatomy, School of Medicine, Kyungpook National University, Daegu, Korea
}

In general, exercise can help improve overall health and prevent diseases. However, individuals with atopic dermatitis (AD) often lose the desire for physical exercise owing to itching caused by sweating. In the present study, we have evaluated the effect of low-intensity tower climbing resistance exercise (TCRE) on Dermatophagoides farinae extract (DFE; house dust mite extract)- and 2,4-dinitrochlorobenzene-induced AD-like skin lesions in a BALB/c model. Histopathological examination showed reduced thickness of the epidermis/dermis and dermal infiltration of inflammatory cells in the ears. TCRE downregulated serum Ig levels and suppressed mRNA expression of pro-inflammatory cyto- kines in the ear tissue, and reduced the size and weight of draining lymph nodes (dLNs) and nondraining lymph nodes (ndLNs), along with expression of pro-inflammatory cytokines in $\mathrm{CD}^{+} \mathrm{T}$ cells from dLNs and ndLNs. Taken together, we showed that low-intensity TCRE reduced AD symptoms. These results will help improve treatment of $A D$, and will be of interest to dermatologists as well as to patients with $A D$.

Keywords: Atopic dermatitis, Tower climbing resistance exercise, Lowintensity exercise

\section{INTRODUCTION}

Atopic dermatitis $(\mathrm{AD})$ is a common chronic or relapsing inflammatory disease associated with pruritic and eczematous skin lesions (Boguniewicz and Leung, 2010; Leung et al., 2004; Savinko et al., 2012). In recent years, the occurrence of $A D$ has rapidly increased in developing and developed countries (Odhiambo et al., 2009; Williams et al., 2008). The etiology of $\mathrm{AD}$ is not clear. However, it is thought to be linked with multifaceted interactions between genetic and environmental factors such as allergens and microbes, as well as between immune and skin barrier dysfunction.

It has also been reported that acute phase $\mathrm{AD}$ is strictly related to $\mathrm{T}$ helper 2 (Th2) cell-mediated lesions, and that chronic AD is related to Th1 cell-mediated AD lesions (Nilsson et al., 2011; Savinko et al., 2012). Furthermore, stimulated mast cells, increased $\operatorname{IgE}, \operatorname{IgG}$, and pro-inflammatory cytokines play key roles in the formation of skin lesions (Niebuhr and Werfel, 2010; Parisi et al., 2013). Several studies have reported that cytokines, includ- ing interleukin (IL)-4, IL-4, IL-13, IL-31, and both tumor necrosis factor-alpha (TNF- $\alpha$ ) and interferon-gamma (IFN- $\gamma$ ) are key players in acute and chronic $\mathrm{AD}$ (Bilsborough et al., 2006; Vestergaard et al., 1999; Yamada et al., 1995). In addition, retinoic acid-related orphan receptor $\gamma \mathrm{T}(\mathrm{ROR} \gamma \mathrm{T})$ is an orphan nuclear receptor that controls the expression of Th17 cells. Consequently, IL-17 has been reported to play a role in certain skin conditions (Albanesi et al., 1999; Zheng et al., 2007). IL-17-producing Th17 cells are important for host immunity. Further, abnormal activation of Th17 cells is responsible for inflammation (McKenzie et al., 2006). Transforming growth factor-beta (TGF- $\beta$ ) is a multifunctional cytokine that is expressed in most tissues, including the skin. TGF- $\beta$ is secreted by several cell types, such as T cells, macrophages, endothelial cells, and keratinocytes, and is known to be involved in different types of skin inflammatory disorders (Khaheshi et al., 2011; Letterio and Roberts, 1998).

Physical exercise is well-known to improve health and prevent disease (Haskell et al., 2007). Systematic physical exercise can
*Corresponding author: Jooyoung Kim (iD https://orcid.org/0000-0002-0526-6559 Department of Anatomy, School of Medicine, Kyungpook National University, 680 gukchaebosang-ro, Jung-gu, Daegu 41944, Korea

E-mail: hirase1125@hanmail.net

Received: May 31, 2019 / Accepted: June 19, 2019
This is an Open Access article distributed under the terms of the Creative Commons Attribution Non-Commercial License (http://creativecommons.org/licenses/by-nc/4.0/) which permits unrestricted non-commercial use, distribution, and reproduction in any medium, provided the original work is properly cited. 
help to reduce body weight and play a key role in the prevention of coronary artery disease, stroke, hypertension, and osteoporosis (Booth and Lees, 2007). However, exercise usually causes sweating, which can result in itching. Many patients with $\mathrm{AD}$ are thought to refrain from exercise because it increases itching. Previous studies have shown that exercise and sweating are major exacerbating factors for patients with AD (Stern et al., 1998; Williams et al., 2004). Nevertheless, regular activity may beneficial to patients with AD (Salzer et al., 1994). However, the connection between low-intensity exercise and $\mathrm{AD}$ has not yet been studied.

In this study, therefore, we examined the effect of low-intensity tower climbing resistance exercise (TCRE) on AD lesions using a $\mathrm{BALB} / \mathrm{c}$ model. The effects were evaluated by assessing ear thickness, histopathological changes including mast cell count, AD-related pro-inflammatory cytokines in ear tissue, and serum immunoglobulin (Ig) levels, as well as the size and weight of draining lymph nodes (dLNs) and nondraining lymph nodes (ndLNs), along with expression of pro-inflammatory cytokines in $\mathrm{CD}^{+} \mathrm{T}$ cells from dLN and ndLNs.

\section{MATERIALS AND METHODS}

\section{Materials}

TRIzol reagent for RNA extraction was purchased from Invitrogen (Carlsbad, CA, USA). Primary antibodies and peroxidase-conjugated secondary antibodies were purchased from Santa Cruz Biotechnology Inc. (Santa Cruz, CA, USA). All other reagents were of the highest grade that was commercially available at the time of the study.

\section{Animals}

Eight-week-old, female BALB/c mice were purchased from Samtako (Samtako Bio Korea Co. Ltd., Osan, Korea) and housed under specific pathogen-free conditions. The animals were housed 5-10 per cage in a laminar air-flow room, maintained at a temperature of $22^{\circ} \mathrm{C} \pm 2{ }^{\circ} \mathrm{C}$, with a relative humidity of $55 \% \pm 5 \%$ throughout the study. All experiments were approved by the Institutional Animal Care and Use Committee of Konkuk University (KU14012).

\section{Induction of AD lesions in the ear and TCRE protocol}

$\mathrm{AD}$ was induced in the mice by repeated local exposure of the ears to Dermatophagoides farinae extract (DFE; house dust mite extract) and 2,4-dinitrochlorobenzene (DNCB), as previously described (Kim et al., 2014). For the induction of $\mathrm{AD}$, the mice were divided into four groups (control, TCRE, AD-only, AD+TCRE). The surfaces of both earlobes were stripped 5 times with surgical tape (Nichiban, Tokyo, Japan). After stripping, $20 \mu \mathrm{L}$ of $1 \%$ DNCB was painted onto each ear, followed 4 days later by 20 $\mu \mathrm{L}$ of DFE $(10 \mathrm{mg} / \mathrm{mL})$. DFE or DNCB treatment was administered alternately once per week for 4 weeks.

The mice climbed the vertical ladder for 4 weeks. The exercise was accomplished utilizing a $1-\mathrm{m}$ ladder with a $1.5-\mathrm{cm}$ grid and inclined at $85^{\circ}$. Initially, the mice climbed with free weights for a week, to become accustomed. For the first training session, a free weight equivalent to $10 \%$ of their body weight was attached to the base of their tail, and the resistance was progressively increased to $30 \%, 50 \%$ for 4 weeks. When the mice reached the top of the ladder, they were allowed to rest for $90 \mathrm{sec}$. The training session was stopped when the mice succeeded to climb the ladder for eight repetitions.

\section{Ear thickness measurement and blood sample preparation}

Ear thickness was measured $24 \mathrm{hr}$ after DNCB or DFE application with a dial thickness gauge (Kori Seiki MFG, Co., Tokyo, Japan). At days 14 and 28, blood samples were collected by the orbital puncture. Plasma samples were prepared from the blood samples and stored at $-70^{\circ} \mathrm{C}$ for further analysis. After blood collection, the ears were removed and used for histopathological analysis. Serum IgE and IgG2a levels were measured at days 14 and 28 after the first induction, using an $\mathrm{IgE}$ enzyme-linked immunoassay kit (Bethyl Laboratories Inc., Montgomery, TX, USA) according to the manufacturer's instructions.

\section{Histological observations}

Excised ears were fixed in 4\% paraformaldehyde for $16 \mathrm{hr}$ and embedded in paraffin. Thin $(6 \mu \mathrm{m})$ sections were stained with hematoxylin and eosin $(\mathrm{H} \& \mathrm{E})$. The thickness of the epidermis and dermis was measured under a microscope. For measurement of mast cell infiltration, skin sections were stained with toluidine blue, after which the number of mast cells was counted in five randomly chosen fields of view.

\section{Real-time polymerase chain reaction}

Quantitative real-time polymerase chain reaction (PCR) was carried out using a Thermal Cycler Dice TP850 (Takara Bio Inc., Shiga, Japan) according to the manufacturer's protocol. Total RNA was isolated from the ear tissue and lymph nodes of each group. The PCR conditions were similar to those previously de- 
scribed (Kim et al., 2014). Briefly, $2 \mu \mathrm{L}$ of cDNA (100 ng), $1 \mu \mathrm{L}$ of sense and antisense primer solution $(0.4 \mu \mathrm{M}), 12.5 \mu \mathrm{L}$ of SYBR Premix Ex Taq (Takara Bio Inc.), and $9.5 \mu \mathrm{L}$ of $\mathrm{dH}_{2} \mathrm{O}$ were mixed to obtain a final $25-\mu \mathrm{L}$ reaction mixture in each reaction tube. The amplification conditions were as follows: $10 \mathrm{sec}$ at $95^{\circ} \mathrm{C}, 40$ cycles of $5 \mathrm{sec}$ at $95^{\circ} \mathrm{C}$ and $30 \mathrm{sec}$ at $60^{\circ} \mathrm{C}, 15 \mathrm{sec}$ at $95^{\circ} \mathrm{C}, 30 \mathrm{sec}$ at $60^{\circ} \mathrm{C}$, and $15 \mathrm{sec}$ at $95^{\circ} \mathrm{C}$. In each sample, the expression level of the analyzed gene was normalized to that of GAPDH and presented as a relative mRNA level.

\section{Statistical analysis}

Statistical analysis was carried out using SAS ver. 9.2 (SAS Institute, Cary, NC, USA). Multiple-group data were analyzed by one-way analysis of variance followed by Dunnett multiple range test. All results are expressed as the mean \pm standard deviation of comparative fold differences. Data are representative of three independent experiments. The threshold for significance was set at $P<0.05$.

\section{RESULTS}

\section{Effect of TCRE on the ear thickness and histopathological observation and on serum lg levels}

Experimental $\mathrm{AD}$ was induced in both earlobes of $\mathrm{BALB} / \mathrm{c}$ mice by the alternative painting of DFE or DNCB for 4 weeks
(Fig. 1A). To evaluate the immunomodulatory effects of TCRE, the mice climbed a vertical ladder for 4 weeks. For the first training session, a free weight equivalent of $10 \%$ of their body weight was attached to the base of the tail, and the resistance was progressively increased to 30\%, 50\% over 4 weeks (Fig. 1B). We found that DFE/DNCB application significantly increased ear thickness and $\mathrm{AD}$ lesions. On the contrary, following TCRE for 4 weeks, we observed that TCRE significantly reduced ear thickness (Fig. 2A, $B)$. The TCRE group mice showed significantly reduced epidermal and dermal thickness (Fig. 2C, E, F). In addition, TCRE reduced numbers of infiltrating immune cells, such as mast cells, compared with the $\mathrm{AD}$ group (Fig. 2D, G).

Mice in the TCRE group showed significantly reduced total and specific IgE (Fig. 2H, I) and IgG2a levels (Fig. 2J) in comparison with those of DFE/DNCB-treated mice. These data suggest that the effect of TCRE in AD progression is related to downregulation of serum Ig levels.

\section{Effect of TCRE on the expression of various pro-inflammatory cytokines in vivo}

We further examined mRNA expression levels of AD-related pro-inflammatory cytokines from ear tissues by real-time PCR. As shown in Fig. 3, mRNA levels of all tested cytokines were upregulated in the ear tissue of $\mathrm{AD}$ mice. On the contrary, the expression of TNF- $\alpha$, INF- $\gamma$, TGF- $\beta 1$, and Th2-related cytokines

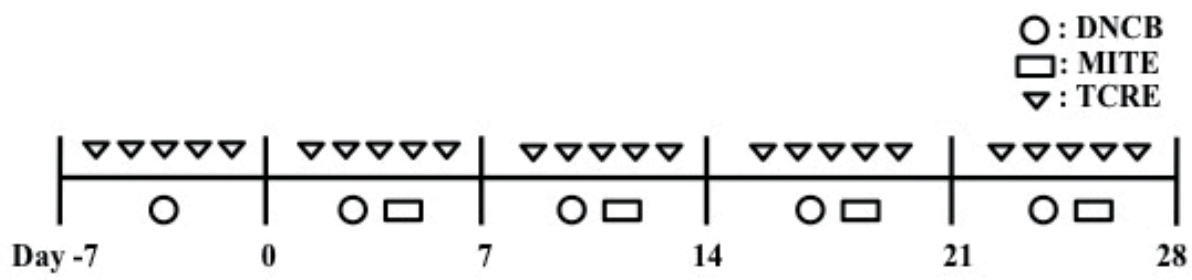

\begin{tabular}{|c|c|c|c|c|c|}
\hline \multirow{2}{*}{ Week } & Adaptation & \multicolumn{4}{|c|}{ Tower climbing resistance exercise periods } \\
\hline & 1 week & 1 & 2 & 3 & 4 \\
\hline $\mathbf{R M}$ & 4 & \multicolumn{4}{|c|}{8} \\
\hline Load & $\mathbf{0} \mathbf{g}$ & \multicolumn{4}{|c|}{$0 \% \rightarrow \mathbf{1 0} \% \rightarrow \mathbf{3 0} \% \rightarrow \mathbf{5 0} \%$ (body weight) } \\
\hline Rest & \multicolumn{5}{|c|}{90 second } \\
\hline Frequency & \multicolumn{5}{|c|}{5 days/week } \\
\hline
\end{tabular}

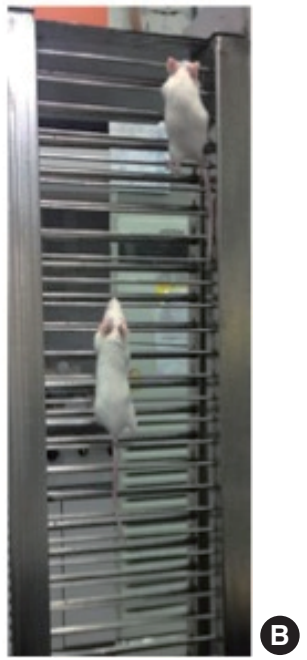

Fig. 1. (A) Experimental schedule for the induction of atopic dermatitis lesions. Mice climbed a vertical ladder for 4 weeks. The exercise was performed utilizing a 1-m ladder with a 1.5-cm grid inclined at $85^{\circ}$. Initially, the mice climbed without free weights for 1 week, to become accustomed to climbing. For the first training session, a free weight equivalent to $10 \%$ of their body weight was attached to the base of their tail, and the resistance was progressively increased to $30 \%, 50 \%$ over 4 weeks. (B) Tower climbing resistance exercise. DNCB, 2,4-dinitrochlorobenzene; TCRE, tower climbing resistance exercise; RM, Repetition maximum. 

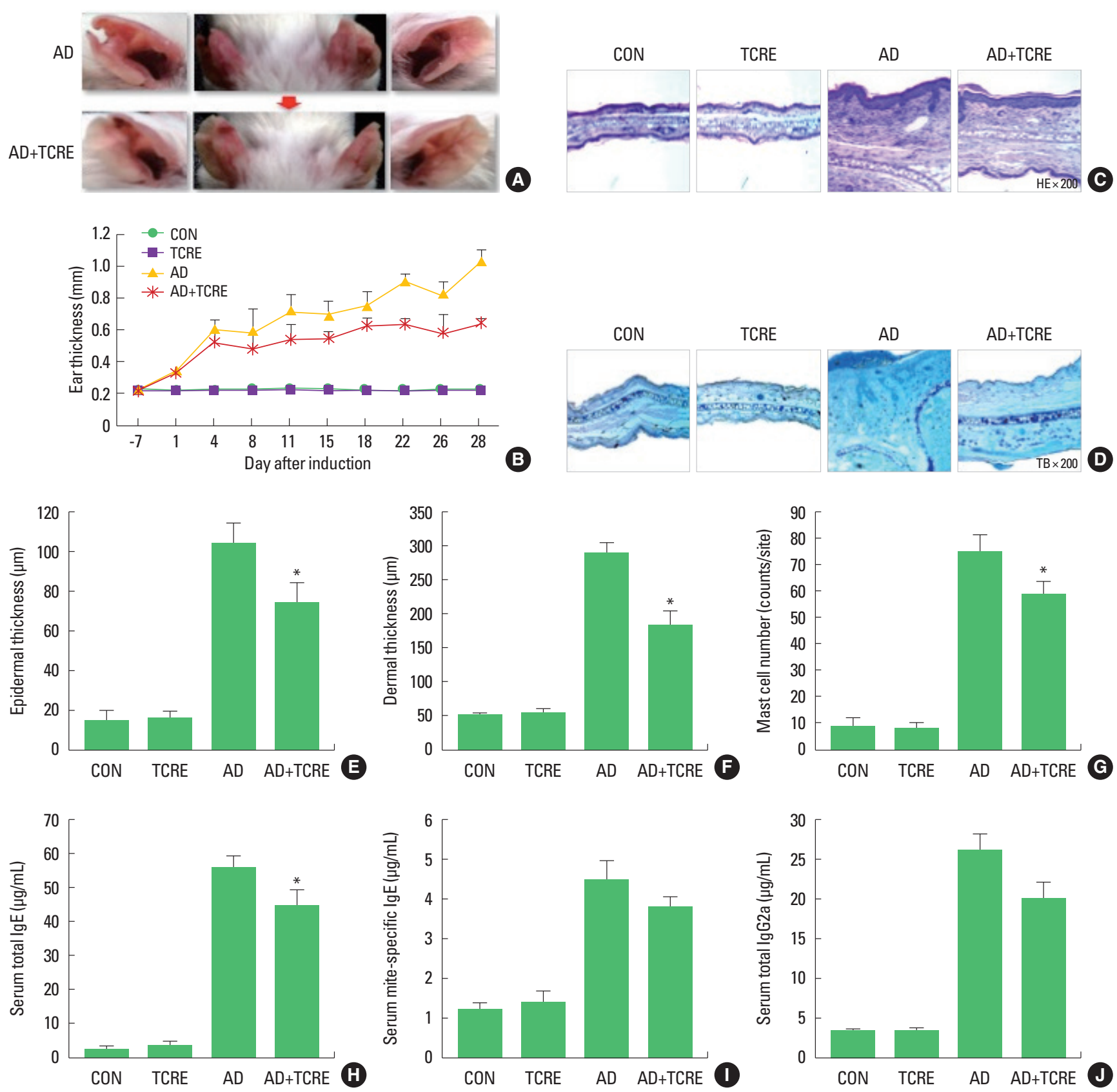

Fig. 2. (A) Photographs of the ears of mice from each group on day 28. (B) Ear thickness was measured with a dial thickness gauge every 3 days after 2,4-dinitrochlorobenzene (DNCB) or Dermatophagoides farinae extract (DFE) application. Representative photomicrographs of ear sections stained with hematoxylin and eosin (C) or toluidine blue (D). Epidermal (E) and dermal (F) thickness was measured using the microphotographs of hematoxylin and eosin-stained tissue. (G) The number of infiltrating mast cells was determined on the basis of toluidine blue staining. Blood samples were collected by an orbital puncture on day 28 . Serum total lgE (H), mite-specific $\lg \mathrm{E}(\mathrm{I})$, and $\lg \mathrm{G} 2 \mathrm{a}(\mathrm{J})$ levels were quantified by enzyme-linked immunosorbent assay. Data are presented as the mean \pm standard deviation of triplicate determinations. ${ }^{*} P<0.05$, a significant difference from the value of the AD mice. AD induced by DFE and DNCB treatment. The pictures shown are representative of each group $(n=3-6)$. The original magnification was $\times 100$. CON, control; TCRE, tower climbing resistance exercise; AD, atopic dermatitis.

such as IL-4, IL-6, IL-10, IL-13, and IL-31 were significantly suppressed in the $\mathrm{AD}+\mathrm{TCRE}$ in the ear tissue. In addition, TCRE significantly reduced the expression of ROR $\gamma \mathrm{T}$ mRNA in the ear tissue (Fig. 3).

Accordingly, we examined the size and weight of dLNs and ndLNs as well as cytokine-related mRNA expression in $\mathrm{CD}^{+} \mathrm{T}$ 

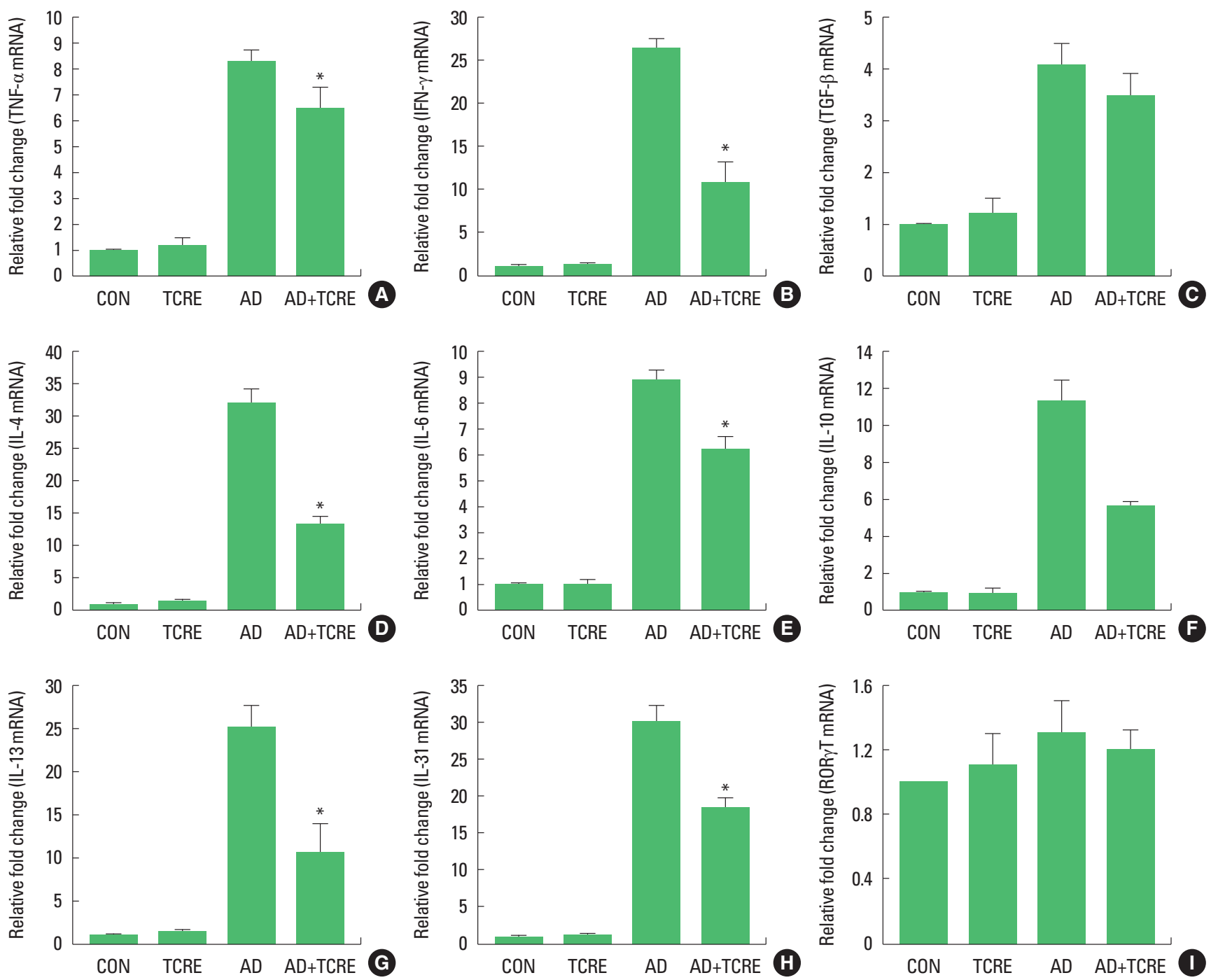

Fig. 3. Effect of tower climbing resistance exercise (TCRE) on the expression of various pro-inflammatory cytokines in the ear. The ears were excised on day 28 and total RNA was isolated. (A-I) The quantitative real-time polymerase chain reaction was performed as described in the Materials and Methods section. Data are presented as the mean \pm standard deviation of triplicate determinations. ${ }^{*} P<0.05$, a significant difference from the value for atopic dermatitis (AD) mice respectively. CON, control; TNF, tumor necrosis factor; IFN, interferon; IL, interleukin; ROR $\gamma$ T, retinoic acid-related orphan receptor gamma T.

cells from dLNs and ndLNs. We observed that AD mice had larger and heavier dLNs than healthy untreated control mice; after 4 weeks of TCRE, the size and weight of dLNs were reduced (Fig. $4 \mathrm{~A}$ ), and no significant differences were observed in the weight of ndLNs between mice in the TCRE and AD groups (Fig. 4A). Analysis of mRNA expression of pro-inflammatory cytokines by $\mathrm{CD} 4^{+} \mathrm{T}$ cells purified from dLNs showed that mice in the $\mathrm{AD}+\mathrm{T}-$ CRE group showed significantly lower dLN expression of TNF- $\alpha$, IFN- $\gamma$, IL-4, IL-13, and IL-17 (Fig. 4B), whereas mRNA expression of pro-inflammatory cytokines was not changed in $\mathrm{CD} 4^{+} \mathrm{T}$ cells purified from ndLNs from the AD+TCRE group (Fig. 4C).

\section{DISCUSSION}

The benefits of exercise have been well studied. Regular physical exercise reduces the risk of several diseases and improves antioxidant activity and immune function (Booth and Lees, 2007; Sen, 1999). However, patients with AD may show a reduced desire for physical exercise due to itching following intense exercise. Therefore, in the present study, we assessed the influence of low-intensity exercise in an $\mathrm{AD}$ model.

The allergic response is linked to mast cells, which originate from myeloid stem cells. Therefore, we performed histological analysis of atopic ears to confirm the visual evaluation of $\mathrm{AD}$ 

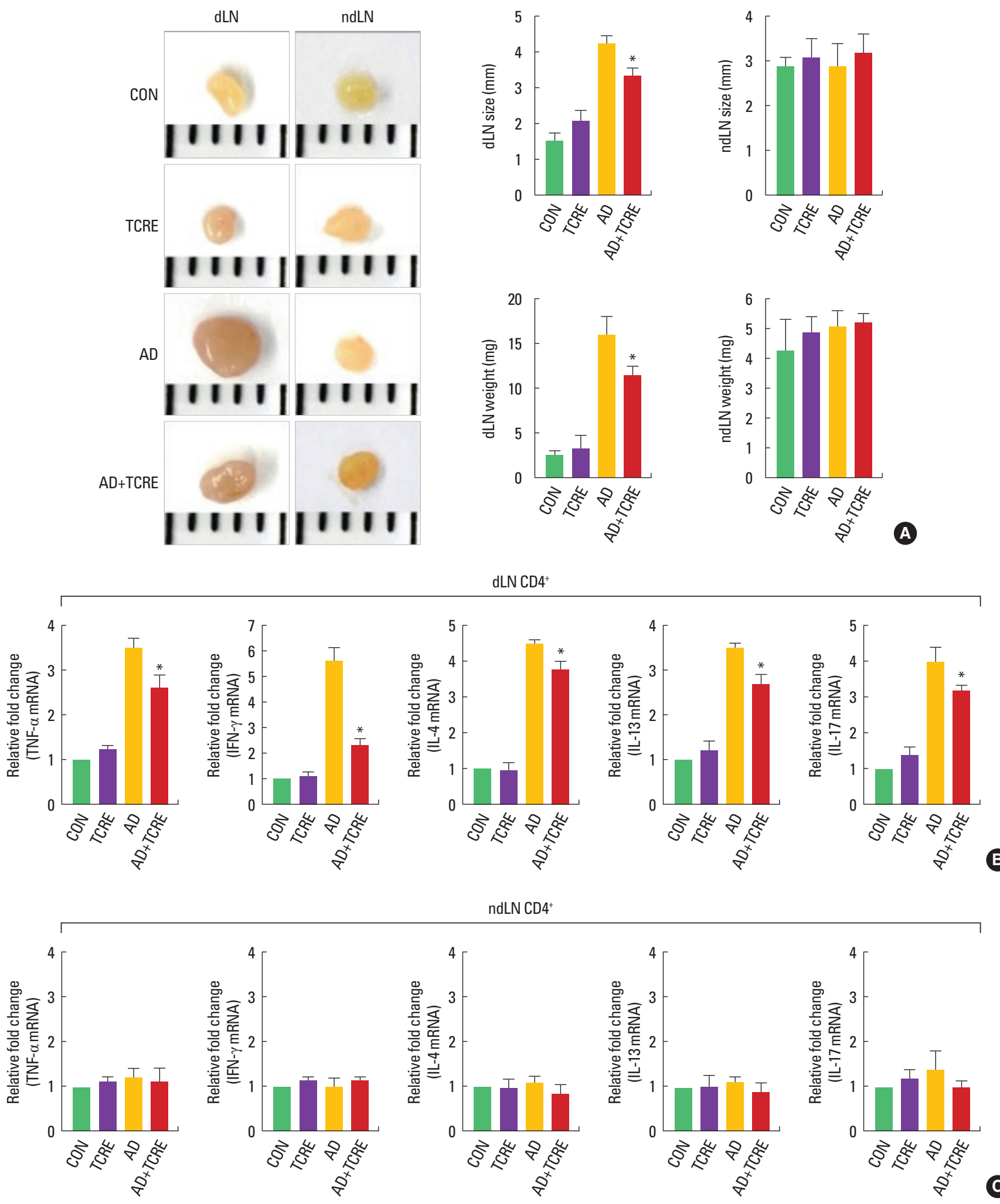

Fig. 4. Effect of tower climbing resistance exercise (TCRE) on the size and weight of draining lymph nodes (dLNs) and nondraining lymph nodes (ndLNs) (A), as well as cytokine-related mRNA expression in $\mathrm{CD}^{+} T$ cells from dLNs $(B)$ and ndLNs $(C)$. ${ }^{*} P<0.05$, a significant difference from the value for atopic dermatitis (AD) mice. CON, control; TNF, tumor necrosis factor; IFN, interferon; IL, interleukin. 
signs. Ears were removed from each group of mice, then stained with $\mathrm{H} \& \mathrm{E}$ or toluidine blue and infiltration of mast cells, and thickening of the epidermis and dermis were observed under a microscope. After TCRE for 4 weeks, TCRE significantly decreased ear thickness epidermal and dermal thickness. In addition, TCRE also reduced numbers of infiltrating mast cells.

Meanwhile, most patients with $\mathrm{AD}$ have increased total serum immunoglobulin IgE levels and specific IgE antibodies to environmental allergens (Dokmeci and Herrick, 2008; Schäfer et al., 1999). Mast cells are stimulated by cross-linking of $\mathrm{IgE}$ and an allergen, which stimulates release of chemical mediators including cytokines at the sites of allergic reactions (Borish and Joseph, 1992). Further, high levels of $\operatorname{IgG}$ antibodies are associated with chronic $\mathrm{AD}$, and $\operatorname{IgG}$ is related to the Th1 response (Mathlouthi and Koenig, 1986). Several studies have also reported that $\mathrm{AD}$ is linked to both Th2 and Th1 cell-mediated lesions and causes increased total IgE levels and Th2/Th1-type cytokine expression (Chen et al., 2004; Grewe et al., 1998; Hamid et al., 1994; Neis et al., 2006). To determine whether these effects are mainly exerted via the Th1 or Th2 response, serum levels of IgE (total and DFE-specific) and IgG2a were measured from each treatment group. Total and specific IgE, and IgG2a levels of $A D+T C R E$ group were significantly reduced compared with $\mathrm{AD}$ group. In addition, TCRE significantly reduced not only Th2 cytokines but also the Th1-related cytokine TNF- $\alpha$, IFN- $\gamma$ and the pro-inflammatory cytokine TGF- $\beta 1$ which was found to be altered in several skin disorders (Khaheshi et al., 2011). Moreover, ROR $\gamma \mathrm{T}$ is essential for the induction of IL-17 transcription and is an indicator of Th17-dependent autoimmune disease in mice. Here, TCRE decreased the ROR $\gamma \mathrm{T}$ level.

Naive $\mathrm{CD} 4^{+} \mathrm{T}$ cells cause the generation of Th1 and Th2 cells in the presence of pathogens. Th1 cells produce TNF- $\alpha$ and IFN- $\gamma$, whereas Th2 cells secrete IL- 4 , IL-13, and IL-17 which promote humoral immunity and $\mathrm{IgE}$ production, as well as regulate Th1 response (Abbas et al., 1996). In particular, IL-4 plays a key role in transforming naive $\mathrm{CD} 4^{+} \mathrm{T}$ cells into Th2 cells (Rincón et al., 1997). Since AD often develops as a systemic disease (Darlenski et al., 2014), we next examined whether TCRE affected systemic immune responses. Larger dLNs were found in mice in the $\mathrm{AD}+\mathrm{TCRE}$ group, compared with mice in the $\mathrm{AD}$ group, and no significant differences were observed in the weight of ndLNs between mice in the TCRE and AD groups. Further, mice in the $\mathrm{AD}+\mathrm{TCRE}$ group showed reduced mRNA expression of TNF- $\alpha$, IFN- $\gamma$, IL-4, IL-13, and IL-17.

Meanwhile, previous studies have reported that exercise and sweating are noteworthy exacerbating factors for the schoolchildren with AD (Stern et al., 1998; Williams et al., 2004). Tay et al. (2002) have also studied AD in Singaporean schoolchildren and reported that exercise, heat, and sweating are the most irritating factors for schoolchildren. Accordingly, Kim et al. (2014) showed that high-intensity swimming exercise increases $\mathrm{AD}$ symptoms in BALB/c mice by increasing Ig and cytokine expression. Contrary to these data, the results of our study show that low-intensity exercise decreases AD symptoms.

In this study, we showed that low-intensity exercise reduces the intensity of DFE/DNCB-induced AD-like skin lesions in BALB/C mice. TCRE downregulated the severity of histopathological symptoms, production of Ig, and mRNA expression of pro-inflammatory cytokines in ear tissue, and reduced the size and weight of dLNs, along with expression of pro-inflammatory cytokines in $\mathrm{CD}^{+} \mathrm{T}$ cells from dLNs. Taken together, our data suggest that TCRE may be beneficial for patients with $\mathrm{AD}$.

\section{CONFLICT OF INTEREST}

No potential conflict of interest relevant to this article was reported.

\section{REFERENCES}

Abbas AK, Murphy KM, Sher A. Functional diversity of helper T lymphocytes. Nature 1996;383:787-793.

Albanesi C, Cavani A, Girolomoni G. IL-17 is produced by nickel-specific T lymphocytes and regulates ICAM-1 expression and chemokine production in human keratinocytes: synergistic or antagonist effects with IFN- $\gamma$ and TNF- $\alpha$. J Immunol 1999;162:494-502.

Bilsborough J, Leung DY, Maurer M, Howell M, Boguniewicz M, Yao L, Storey H, LeCiel C, Harder B, Gross JA. IL-31 is associated with cutaneous lymphocyte antigen-positive skin homing $\mathrm{T}$ cells in patients with atopic dermatitis. J Allergy Clin Immunol 2006;117:418-425.

Boguniewicz M, Leung DY. Recent insights into atopic dermatitis and implications for management of infectious complications. J Allergy Clin Immunol 2010;125:4-13

Booth FW, Lees SJ. Fundamental questions about genes, inactivity, and chronic diseases. Physiol Genomics 2007;28:146-157.

Borish L, Joseph BZ. Inflammation and the allergic response. Med Clin North Am 1992;76:765-787.

Chen L, Martinez O, Overbergh L, Mathieu C, Prabhakar BS, Chan LS. Early up-regulation of Th2 cytokines and late surge of Th1 cytokines in an atopic dermatitis model. Clin Exp Immunol 2004;138:375-387. 
Darlenski R, Kazandjieva J, Hristakieva E, Fluhr JW. Atopic dermatitis as a systemic disease. Clin Dermatol 2014;32:409-413.

Dokmeci E, Herrick CA. The immune system and atopic dermatitis. Semin Cutan Med Surg 2008;27:138-143.

Grewe M, Bruijnzeel-Koomen CA, Schöpf E, Thepen T, Langeveld-Wildschut AG, Ruzicka T, Krutmann J. A role for Th1 and Th2 cells in the immunopathogenesis of atopic dermatitis. Immunol Today 1998;19: 359-361.

Hamid Q, Boguniewicz M, Leung DY. Differential in situ cytokine gene expression in acute versus chronic atopic dermatitis. J Clin Invest 1994; 94:870-876.

Haskell WL, Lee IM, Pate RR, Powell KE, Blair SN, Franklin BA, Macera CA, Heath GW, Thompson PD, Bauman A; American College of Sports Medicine; American Heart Association. Physical activity and public health: updated recommendation for adults from the American College of Sports Medicine and the American Heart Association. Circulation 2007;116:1081-1093.

Khaheshi I, Keshavarz S, Imani Fooladi AA, Ebrahimi M, Yazdani S, Panahi $Y$, Shohrati M, Nourani MR. Loss of expression of TGF- $\beta$ s and their receptors in chronic skin lesions induced by sulfur mustard as compared with chronic contact dermatitis patients. BMC Dermatol 2011; $11: 2$

Kim SH, Kim EK, Choi EJ. High-intensity swimming exercise increases dust mite extract and 1-chloro-2,4-dinitrobenzene-derived atopic dermatitis in BALB/c mice. Inflammation 2014;37:1179-1185.

Letterio JJ, Roberts AB. Regulation of immune responses by TGF- $\beta$. Annu Rev Immunol 1998;16:137-161.

Leung DY, Boguniewicz M, Howell MD, Nomura I, Hamid QA. New insights into atopic dermatitis. J Clin Invest 2004;113:651-657.

Mathlouthi M, Koenig JL. Vibrational spectra of carbohydrates. Adv Carbohydr Chem Biochem 1986;44:7-89.

McKenzie BS, Kastelein RA, Cua DJ. Understanding the IL-23-IL-17 immune pathway. Trends Immunol 2006;27:17-23.

Neis MM, Peters B, Dreuw A, Wenzel J, Bieber T, Mauch C, Krieg T, Stanzel S, Heinrich PC, Merk HF, Bosio A, Baron JM, Hermanns HM. Enhanced expression levels of IL-31 correlate with IL-4 and IL-13 in atopic and allergic contact dermatitis. J Allergy Clin Immunol 2006;118: 930-937.

Niebuhr M, Werfel T. Innate immunity, allergy and atopic dermatitis. Curr Opin Allergy Clin Immunol 2010;10:463-468.

Nilsson OB, Adedoyin J, Rhyner C, Neimert-Andersson T, Grundström J, Berndt KD, Crameri R, Grönlund $H$. In vitro evolution of allergy vaccine candidates, with maintained structure, but reduced $\mathrm{B}$ cell and $\mathrm{T}$ cell activation capacity. PLoS One 2011;6:e24558.

Odhiambo JA, Williams HC, Clayton TO, Robertson CF, Asher MI; ISAAC
Phase Three Study Group. Global variations in prevalence of eczema symptoms in children from ISAAC Phase Three. J Allergy Clin Immunol 2009;124:1251-1258.

Parisi CA, Smaldini PL, Gervasoni ME, Maspero JF, Docena GH. Hypersensitivity reactions to the Sabin vaccine in children with cow's milk allergy. Clin Exp Allergy 2013;43:249-254.

Rincón M, Anguita J, Nakamura T, Fikrig E, Flavell RA. Interleukin (IL)-6 directs the differentiation of IL-4-producing CD4+ T cells. J Exp Med 1997;185:461-469.

Salzer B, Schuch S, Rupprecht M, Hornstein OP. Group sports as adjuvant therapy for patients with atopic eczema. Hautarzt 1994;45:751755.

Savinko T, Matikainen S, Saarialho-Kere U, Lehto M, Wang G, Lehtimäki S, Karisola P, Reunala T, Wolff H, Lauerma A, Alenius H. IL-33 and ST2 in atopic dermatitis: expression profiles and modulation by triggering factors. J Invest Dermatol 2012;132:1392-1400.

Schäfer T, Heinrich J, Wjst M, Adam H, Ring J, Wichmann HE. Association between severity of atopic eczema and degree of sensitization to aeroallergens in schoolchildren. J Allergy Clin Immunol 1999;104:1280-1284.

Sen CK. Glutathione homeostasis in response to exercise training and nutritional supplements. Mol Cell Biochem 1999;196:31-42.

Stern UM, Salzer B, Schuch S, Hornstein OP. Sex-dependent differences in sweating of normal probands and atopic patients in cardiovascular stress. Hautarzt 1998;49:209-215.

Tay YK, Kong KH, Khoo L, Goh CL, Giam YC. The prevalence and descriptive epidemiology of atopic dermatitis in Singapore school children. Br J Dermatol 2002;146:101-106.

Vestergaard C, Yoneyama H, Murai M, Nakamura K, Tamaki K, Terashima Y, Imai T, Yoshie O, Irimura T, Mizutani H, Matsushima K. Overproduction of Th2-specific chemokines in NC/Nga mice exhibiting atopic dermatitis-like lesions. J Clin Invest 1999;104:1097-1105.

Williams H, Stewart A, von Mutius E, Cookson W, Anderson HR; International Study of Asthma and Allergies in Childhood (ISAAC) Phase One and Three Study Groups. Is eczema really on the increase worldwide? J Allergy Clin Immunol 2008;121:947-954.

Williams JR, Burr ML, Williams HC. Factors influencing atopic dermatitis-a questionnaire survey of schoolchildren's perceptions. Br J Dermatol 2004;150:1154-1161.

Yamada N, Wakugawa M, Kuwata S, Yoshida T, Nakagawa H. Chronologic analysis of in situ cytokine expression in mite allergen-induced dermatitis in atopic subjects. J Allergy Clin Immunol 1995;96(6 Pt 2): 1069-1075.

Zheng Y, Danilenko DM, Valdez P, Kasman I, Eastham-Anderson J, Wu J, Ouyang W. Interleukin-22, a $\mathrm{T}_{\mathrm{H}} 17$ cytokine, mediates IL-23-induced dermal inflammation and acanthosis. Nature 2007;445:648-651. 